\title{
INDIGENOUS VESICULAR MYCORRHIZAL FUNGI EFFECT ON MAIZE UNDER DIFFERENT TEXTURES
}

\author{
Fariha Ilyas ${ }^{1,}{ }^{*}$, M. Arif ${ }^{2}$, Aysha Iftikhar ${ }^{1}$, Asma Sattar $^{3}$, Do Minh Cuong ${ }^{4}$, Mehwish Ilyas $^{5}$, Amna Parveen ${ }^{1}$ \\ ${ }^{1}$ Department of Soil Science \\ ${ }^{2}$ Assistant Professor, Department of Soil Science \\ ${ }^{3}$ Department of Structures and Environmental Engineering \\ ${ }^{4}$ Hue University of Agriculture and Forestry, Hue University, Hue city, Vietnam \\ 5 Independent Researcher \\ *Corresponding Author email: aafma54321@gmail.com
}

This is an open access article distributed under the Creative Commons Attribution License, which permits unrestricted use, distribution, and reproduction in any medium, provided the original work is properly cited.

\section{ARTICLE DETAILS}

\section{Article History:}

Received 26 June 2018

Accepted 2 July 2018

Available online 1 August 2018

\section{ABSTRACT}

Plant health and biomass relies on nutrient availability and the efficiency with which nutrients are taking in by plants. Vesicular Arbuscular Mycorrhiza (VAM) is a symbiotic association between plant roots and fungus. VAM improve plant growth by modifying its rhizosphere soil and helps in nutrient uptake by plants. Our aim was to evaluate the growth of maize (Zea mays) and quantify mycorrhizae under different textures and in phosphorous deficient soils. Treatments include different types of soil texture (pure soil, pure sand and 1:1 soil+sand) along with recommended rate of nitrogen and potassium fertilizer while no phosphorous fertilizer was used. Root colonization, growth rate of plant, biomass of plant root and shoot and effect of VAM and roots on rhizosphere soil $\mathrm{pH}$ were observed. Results showed that shoot biomass was significantly improved in plain soil treatment as compared to sandy texture soils. Root:shoot ratio was significantly decreased in plain soil as compared to plants in sand. $\mathrm{pH}$ was reduced in all treatments significantly. Root colonization ranges from $40-49 \%$ and colonization rates higher in sandy soils than others. Results suggested that VAM infection show well growth in its natural environment and improve plant growth and yield.

\section{KEYWORDS}

Vesicular Arbuscular Mycorrhizae, Maize, Phosphorous, Root, Shoot.

\section{INTRODUCTION}

Vesicular arbuscular mycorrhizae (VAM) may have been described as early as 1842 [1]. VAM are present in the roots of almost all vascular plants [2]. These common soil-borne fungi belong to the family, the Zygomycotina and produce extensive fungal structures in the cortex of the roots [3]. They are reported from angiosperms (most agriculture crops), gymnosperms, pteridophytes and bryophytes. It is abundant in warmer climates with dry soils, pasture lands. Vesicular arbuscular mycorrhizae increase exploited soil volume by roots of plants [4]. Due to this increased volume, VAM association often results in increased uptake of immobile nutrient elements especially of P [5].

Mycorrhizae greatly influence on plant physiology and growth. Role of mycorrhizal fungi on plant community and ecosystem will be the next step of research focusing fungi [6]. Mycorrhizal association is widely spread over different textures of soil and important for many plants. Mycorrhizae can alleviate the harmful effects of heavy metals, soil compaction, salinity and drought on plants [7]. Mycorrhizae contribute to soil structure in ecosystem. Soil structure is the aggregation or clumping of soil particles due to organic complexes and pore spaces.

Vesicular arbuscular mycorrhizae increase exploited soil volume by roots of plants [8]. Due to this increased volume, VAM association often results in increased uptake of immobile nutrient elements especially of $P$ [5]. This is due to various mechanisms suggested for the increase in the uptake of $P$ by mycorrhizal plants which include: exploration of larger soil volume; faster movement of P into mycorrhizal hyphae; and solubilization of soil phosphorus [8]. Uptake of ions, colonization and root expressions differs among plants and VAM species [9-11]. Type of mycorrhiza depends upon environmental conditions such as climate, organic matter and its decomposition rate, soil nutrient contents and plant photosynthetic activity rate. The experiment was designed to study the behavior of indigenous mycorrhizal association and effect on maize, grown in different texture soils.

\section{MATERIALS AND METHODS}

A pot experiment was designed in a weir house at the Faculty of Agricultural Sciences \& Technology, Bahauddin Zakariya University Multan, during the months of February-April. The experiment was designed to study the behavior of mycorrhizal association and effect on maize grown in different texture soils. Undisturbed bulk surface $(0-15 \mathrm{~cm})$ soil samples were collected from forest area (soil A), citrus orchard (Soil B) and from weir house of Agriculture department, Bahauddin Zakariya University (Soil C), Multan. Soils were taken from undisturbed soils because mycorrhizal association is mostly found in undisturbed soil. It was thoroughly mixed for homogenized and uniform experimental material. Soil $\mathrm{pH}$, electrical conductivity is determined by the recommended methods of ICARDA. Maize is used as test crop. Sand is used as control. $\mathrm{T}_{0}=$ Sand, $\mathrm{T}_{1}=$ Soil $(\mathrm{A}+\mathrm{B}+\mathrm{C}), \mathrm{T}_{2}=50 \%$ Sand $+50 \%$ Soils $(A+B+C)$. Treatments comprising of sand, soils and sand plus soil were arranged with four replicates according to CRD design.

Tap water was used for maintaining optimum moisture of plants. Plants were irrigated on daily basis according to their requirement.

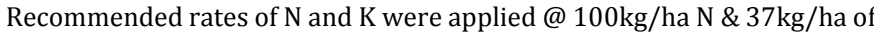
$\mathrm{K}$ using urea $\left[\left(\mathrm{NH}_{2}\right)_{2} \mathrm{CO}\right]$ and Potassium Sulfate $\left(\mathrm{K}_{2} \mathrm{SO}_{4}\right)$ after $20 \& 35$ days of sowing a dose of fertilizer was added. Plant growth rate is measured on weekly basis. Crop was harvested 50 days after sowing. 
Shoot samples were removed from each pot and were collected in separate paper bags that were labeled accordingly. Then soil form each pot was washed away to collect root sample and almost 50g of soil sample was taken from each pot to check the $\mathrm{pH}$ and $\mathrm{EC}$ of rhizosphere to observe the effects of mycorrhizae and roots. Soil samples were air dried for 48 hours. Fresh weight of shoot and root samples were measured. Oven dried samples root:shoot ratio was measured. Roots were stained by Jan Jansa method, which allows colonization of roots by AMF to measure the association under different textures of soil.

\section{RESULTS AND DISCUSSION}

Vesicular arbuscular mycorrhizae colonize its roots and significantly increase its growth rate, nutrient uptake. VAM not only positively affects plant growth but also impacts positively on rhizosphere soil and increase nutrient availability to roots. It effects on Root: Shoot ratio of plant species. VAM response varies from plant species to species, texture to texture of soil.

\subsection{Root: Shoot Ratio}

Results show that root: shoot ratio is 1.5 in $\mathrm{T}_{0}$ and 1.4 in $\mathrm{T}_{1}$. Root: shoot ratio was found to be negatively related with growth. It increases during stress conditions like moisture stress, salt stress, less availability of nutrients. There was general trend that root: shoot ratio to increase as soil texture changes from clay to sand [12]. Root: Shoot ratio is high in $\mathrm{T}_{0}$, because of less ability of retaining moisture and nutrients in sand. Root: Shoot ratio decreases as the moisture availability increases [13-15]. $\mathrm{T}_{1}$ has more ability to retain nutrient and moisture as compared to $T_{0}$ and $T_{2}$, because of more clay and silt content in $\mathrm{T}_{1}$.

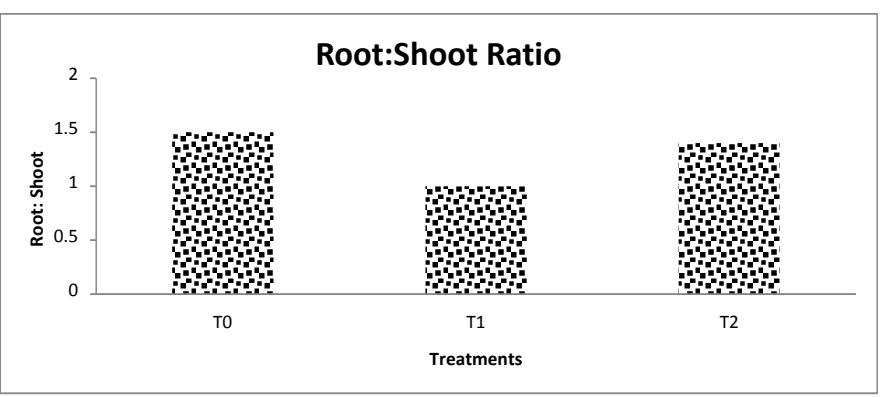

Figure 1: Root: Shoot ratio is high in T0 (sand) and T2 (Sand+Soil), because of stress on these treatment plants as compared to T1 (soil).

\subsection{Plant Biomass}

The results showed that the fresh and dry weight of shoots increased as the soil concentration increased. The treatment having high soil contents has greatest biomass. Naturally occurring mycorrhizae in soil affected the plant significantly. Plants colonized by AMF also have greater ability to absorb nutrients like $\mathrm{P}, \mathrm{N}, \mathrm{K}, \mathrm{Ca}, \mathrm{Mg}$, and water which results in better survival under stressed conditions [16].

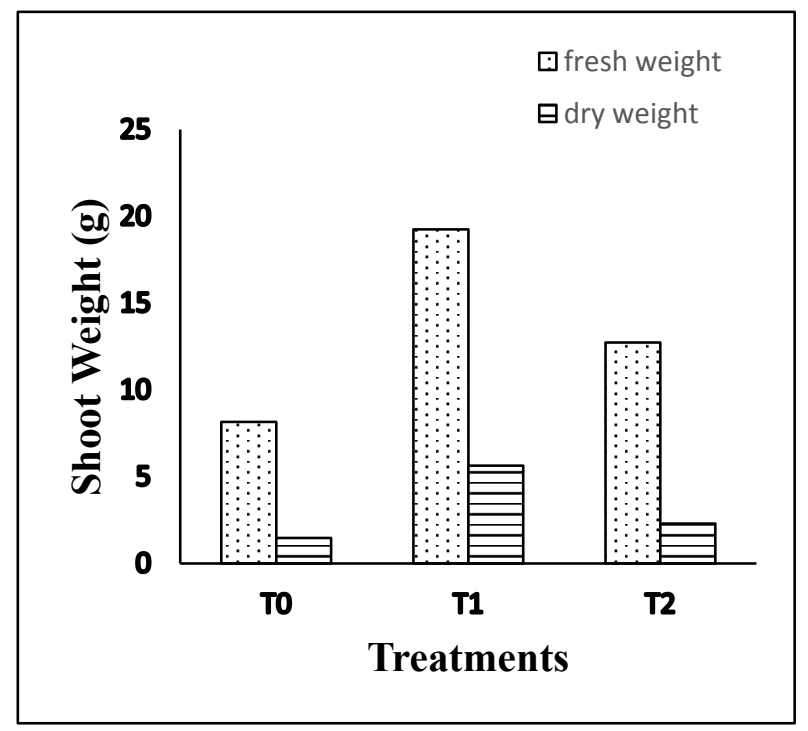

Figure 2: Fresh \& dry weight of plant shoots showing high biomass in treatment with more soil content as compared to treatment with sand only

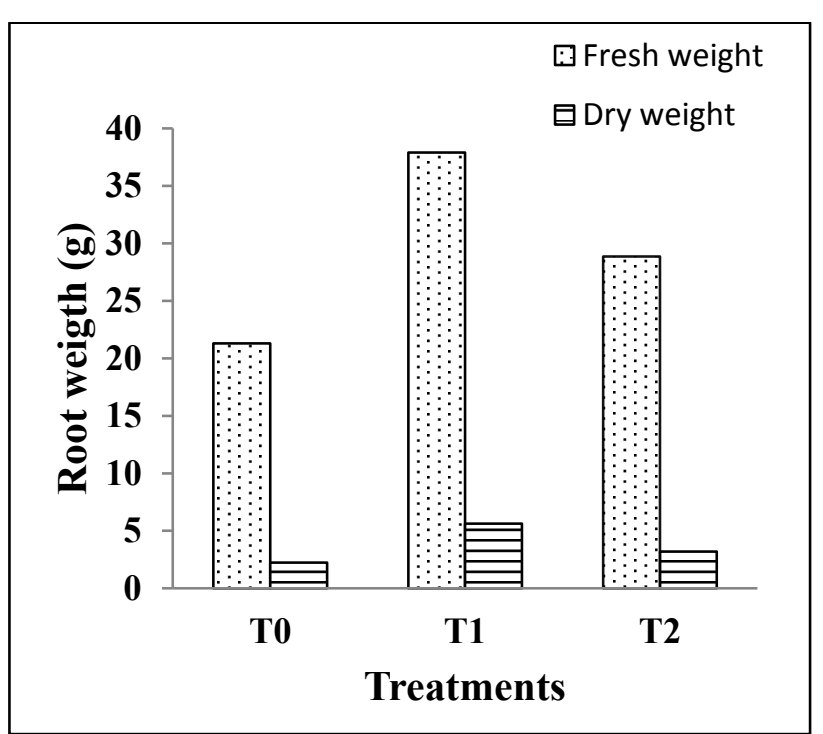

Figure 3: Fresh and dry weight of plant roots presents more root biomass in $\mathrm{T} 1$.

\subsection{Change in EC and pH}

The result shows that there is a decrease in rhizosphere soil pH. It may be increase or decrease up to two units in the rhizosphere owing to be release and uptake of ions by roots. Root induced changes affects the mineral nutrition of plants by various methods. Root exudates solubilize iron an aluminum phosphates cause net excretion of $\mathrm{H}^{+}$in soil solution and increase in reducing capacity [17]. Respiration of microflora in rhizosphere alters soil $\mathrm{pH}$. More activity and population of microflora, then $\mathrm{pH}$ of rhizosphere lowers than that of surrounding soil.
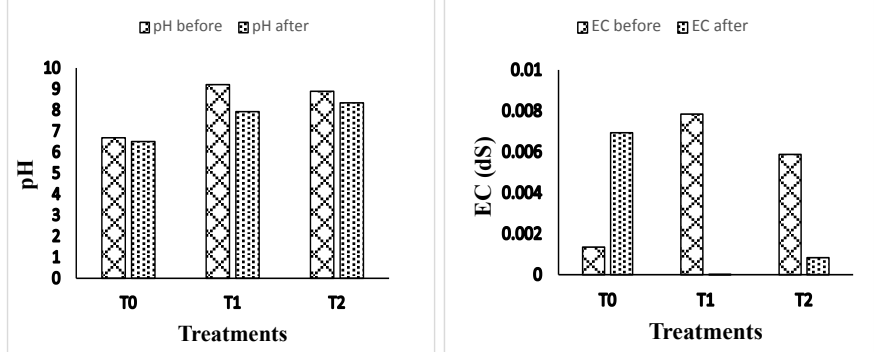

Figure 4: $\mathrm{a}$ and $\mathrm{b}$ shows $\mathrm{pH}$ and $\mathrm{EC}$ of soil. There is a decline in rhizosphere $\mathrm{pH}$ of all treatments while $\mathrm{pH}$ of $\mathrm{T}_{1}$ decline significantly after harvesting of plant.

\subsection{Growth Rate}

There was significantly change in growth parameter among different soil texture treatments. Growth rate was high in treatment which had more soil contents as compared to sand. The results showed that the plant height increased $\mathrm{T}_{1}$. Whereas the treatments with $100 \%$ sand $\left(\mathrm{T}_{0}\right)$ and $50 \%$ sand $\left(\mathrm{T}_{2}\right)$ had plants with less height, comparatively. As the plant grow on seed nutrients, emergence of plants and the width of plant leaves were good in sandy soil $\left(\mathrm{T}_{0}\right)$ as compared to other treatments. Later when plant depended on soil for nutrient uptake, its growth declined because sand has poor nutrient availability. The results showed that the plants grown in soil with naturally occurring mycorrhizae have better leaves width and growth. Number of leaves per pot showed similar results in all treatments. $T_{2}$ plants growth was in between both treatments. We concluded that the plants of $\mathrm{T}_{1}$ had good nutrient availability which leads to better vegetative growth of plants.

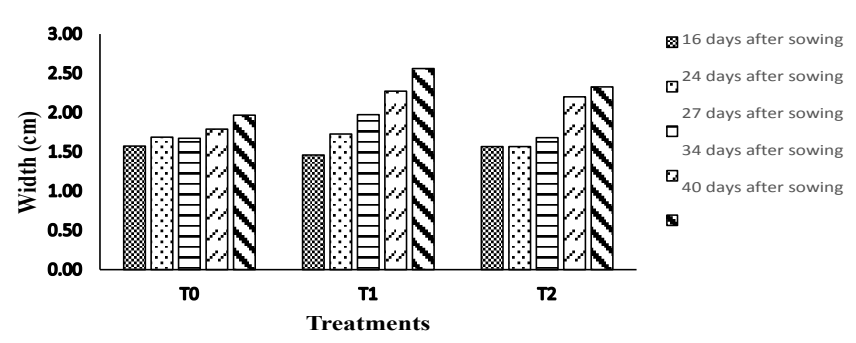



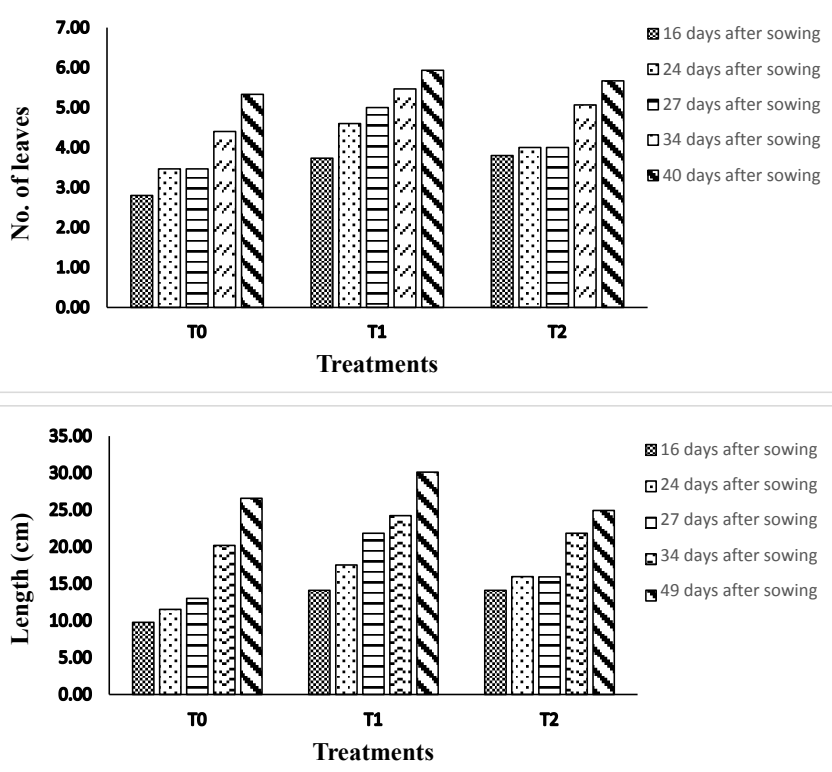

Figure 5: a, b, c shows the physical increment in growth rate e.g. width of leaves, number of leaves and length of leaves respectively.

Length \& width of leaves was more prominent in sand during the early stage of plant growth but after utilization of stored food in seed, growth rate start declining. Number of leaves was almost same in all treatments. Treatment with more soil content show better results as compare to others because of more availability of nutrients and more moisture retaining capacity as compared to other treatments.

\subsection{Root Colonization}

Root colonization is high in $\mathrm{T}_{0}$ treatments. In general, clayey soils are more fertile than sandy ones because clay has a higher capacity for adsorbing ions from the soil solution [18]. High cationic exchange capacity was observed in the clayey soil, and this greater nutrient concentration could have limited VAM development, as shown in several studies $[19,20]$. Additionally, the mechanical impediment, caused by a finer soil texture, favors the deposition of suberin on the epidermis, which increases resistance to infection by VAM [21-23]. With reduced space between the soil particles, mechanical stress on the roots is increased, so that breakage of the cortical layers is increased and the colonization sites are lost.

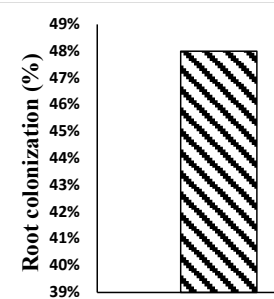

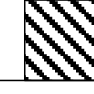

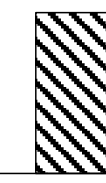

Treatments

Figure 6: VAM colonization is high in T0 (Sand), because sandy soils have more pores, more soil temperature and less nutrients which favors the growth of roots and less nutrients availability. Nutrient availability retards the growth of mycorrhizae $[19,20]$.

Sandy soils are usually more porous, warmer, drier, and less fertile than those of a finer texture and these conditions have direct and indirect effects on AMF [24]. Good soil aeration is a prerequisite for optimum AMF development [25]. Soil temperature from 30 to $35^{\circ} \mathrm{C}$ favors spores germination, spread of root colonization and arbuscule formation [26, 27]. Soils with low fertility limit plant development and increase the dependence of plants on mycorrhizal association. Under these circumstances, fungi grow more extensively inside the root to support the development and functioning of external hyphae. Arbuscles are important structures for nutrient exchange and were observed on 10 to $48 \%$ of the roots examined indicating a functional interaction between AMF and plant.

\section{CONCLUSIONS}

From above discussion it is concluded that VAM showed better result in medium texture soil as compared to clayey and sandy. By this research, it was confirmed that root colonization is better in coarse textured soils as compared to fine textured soil. In this experiment, VAM colonization was more in loose texture soil and affect growth parameter and improve plant growth. To analyze the growth factor further experiments be will conducted by the scientists in future.

\section{REFERENCES}

[1] Agriculture. 2017. Ministry of Finance [online]. Available at <http://www.finance.gov.pk/survey/chapters_16/02_Agriculture.pdf $>$ Accessed on April 1, 2017

[2] Arihara, J., Karasawa, T. 2000. Effect of previous crops on arbuscular mycorrhizal formation and growth of succeeding maize. Soil Sci. Plant Nutr, 46 (1), 43-51.

[3] Bona, E., Cantamessa, S., Massa, N., Manassero, P., Marasno, F., Copetta, A., Lingua, G., Agostino, G.D., Gamalero, E., Berta, G. 2016. Arbuscular mycorrhizal fungi and plant growth-promoting pseudomonads improve yield, quality and nutritional value of tomato: a field study. Mycorrhiza, 27, $1-11$.

[4] Carrenho R., Trufem, S.F.B., Bononi, V.L.R., Silva, E.S. 2007. The effect of different soil properties on arbuscular mycorrhizal colonization of peanuts, sorghum and maize. Acta Botanica Brasilica, 21, 723-730.

[5] Castelli, M., Urcoviche, R.C., Gimenes, R.M.T., Alberton, O. 2014. Arbuscular mycorrhizal fungi diversity in maize under different soil managements and seed treatment with fungicide. Journal of Food, Agriculture and Environment, 12 (2), 486-491.

[6] Charron, G., Furlan, V., Bernier-Cardou, M., Doyon, G. 2001. Response of onion plants to arbuscular mycorrhizae 2. Effects of nitrogen fertilization on biomass and bulb firmness. Mycorrhiza, 11 (3), 145-150.

[7] Cheeke, T.E., Darby, H., Rosenstiel, T.N., Bever, J.D., Cruzan, M.B. 2014. Effect of Bacillus thuringiensis (Bt) maize cultivation history on arbuscular mycorrhizal fungal colonization, spore abundance and diversity, and plant growth. Agriculture, Ecosystems \& Environment, 195, 29-35.

[8] Cozzolino, V., Di Meo, V., Piccolo, A. 2013. Impact of arbuscular mycorrhizal fungi applications on maize production and soil phosphorus availability. Journal of Geochemical Exploration, 129, 40-44.

[9] Del-Saz, N.F., Munar, A.R., Cawthray, G.R., Aroca, R., Bazara, E., Flexas, J., Lambers, H., Carbo, M.R. 2017. Arbuscular mycorrhizal fungus colonization in Nicotiana tabacum decreases the rate of both carboxylate exudation and root respiration and increases plant growth under phosphorus limitation. Plant Soil, 1-10.

[10] Feng, Y., Cui, X., He, S., Dong, G., Chen, M., Wang, J., Lin, X. 2013. The role of metal nanoparticles in influencing arbuscular mycorrhizal fungi effects on plant growth. Environmental Science \& Technology, 47 (16), 9496-504.

[11] Gianinazzi-Pearson, V. 1996. Plant cell responses to arbuscular mycorrhizal fungi: getting to the roots of the symbiosis. Plant Cell, 8, 18711883.

[12] Gollner, M.J., Püschel, D., Rydlová, J., Vosátka, M. 2006. Effect of inoculation with soil yeasts on mycorrhizal symbiosis of maize. Pedobiologia (Jena), 50 (4), 341-345.

[13] Graham, J.H. 2000. Assessing costs of arbuscular mycorrhizal symbiosis in agroecosystems. In Current Advances in Mycorrhizal Research. Eds. G. K. Podila and D. D. Douds Jr. pp: 127-140. APS Press, St. Paul, MN.

[14] Haghighi, M., Mohammadania, S., Pessarkli, M. 2016. Effects of mycorrhiza colonization on growth, root exudates, antioxidant activity and photosynthesis trait of cucumber grown in Johnson modified nutrient solution. Journal of Plant Nutrition, 39.

[15] Imaz, P.A., Barbieri, P.A., Echeverría, H.E., Rozas, H.R.S., Covacevich, F. 2014. Indigenous mycorrhizal fungi from Argentina increase Zn nutrition of maize modulated by Zn fertilization. Soil Environ, 33 (1), 23-32.

[16] INVAM. 2017. Extraction of spores. Available at http://www.invam.wvu.edu/methods/spores. Accessed on 29 March 2017.

[17] Karasawa, T., Ariharal, J., Kasahara, Y. 2000a. Effects of previous crops 
on arbuscular mycorrhizal formation and growth of maize under various soil moisture conditions. Soil Science and Plant Nutrition, 46 (1), 53-60.

[18] Karasawa, T., Takebe, M., Kasahara, Y. 2000. Arbuscular mycorrhizal (AM) effects on maize growth and AM colonization of roots under various soil moisture conditions. Soil Science and Plant Nutrition, 46 (1), 61-67.

[19] Koide, R.T., Mosse B. 2004. A history of research on arbuscular mycorrhiza. Mycorrhizae, 14, 145-163.

[20] Koziol, L., Bever, J.D. 2015. Mycorrhizal response trades off with plant growth rate and increases with plant successional status. Ecology, 96 (7), $1768-1774$.

[21] Merlos, M.A., Zitka, O., Vojtech, A., Aguilar, C.A., Ferrol, N. 2016. The arbuscular mycorrhizal fungus rhizophagus irregularis differentially regulates the copper response of two maize cultivars differing in copper tolerance. Soil Science and Plant Nutrition, 253, 68-76.

[22] Miller, M.H. 2000. Arbuscular mycorrhizae and the phosphorus nutrition of maize: A review of Guelph studies. Canadian Journal of Plant Science, 80, 47-52.
[23] Mohamed, A.A., Eweda, W.E.E., Heggo, A.M., Hassan, E.A. 2014. Effect of dual inoculation with arbuscular mycorrhizal fungi and sulphuroxidising bacteria on onion (Allium cepa L.) and maize (Zea mays L.) grown in sandy soil under greenhouse conditions. Annals of Agricultural Sciences, 59 (1), 109-118.

[24] Mokany, K., Raison, R.J., Prokushkin, A.S. 2006. Critical analysis of root: shoot ratios in terrestrial biomes. Global Change Biology, 12, 84-96.

[25] Pakkisan. 2017. All about/ crop/ Maize. Available at <http://www.pakissan.com/english/allabout/crop/maize.shtml>. Accessed on 26 March 2017.

[26] Sheng, M., Tang, M., Chen, H., Yang, B., Zhang, F., Huang, Y. 2009. Influence of arbuscular mycorrhizae on the root system of maize plants under salt stress. Canadian Journal of Microbiology, 55 (7), 879-86.

[27] Staddon, P.L., Fitter, A.H., Robinson, D. 1999. Effects of mycorrhizal colonization and elevated atmospheric carbon dioxide on carbon fixation and below-ground carbon partitioning in Plantago lanceolata. Journal of Experimental Botany, 50, 853-858. 